\title{
Updated Overview of Infrared Spectroscopy Methods for Detecting Mycotoxins on Cereals (Corn, Wheat, and Barley)
}

\author{
Cecile Levasseur-Garcia \\ INPT, INP-Purpan, Université de Toulouse, 31076 Toulouse, France; cecile.levasseur@purpan.fr
}

Received: 27 November 2017; Accepted: 3 January 2018; Published: 10 January 2018

\begin{abstract}
Each year, mycotoxins cause economic losses of several billion US dollars worldwide. Consequently, methods must be developed, for producers and cereal manufacturers, to detect these toxins and to comply with regulations. Chromatographic reference methods are time consuming and costly. Thus, alternative methods such as infrared spectroscopy are being increasingly developed to provide simple, rapid, and nondestructive methods to detect mycotoxins. This article reviews research conducted over the last eight years into the use of near-infrared and mid-infrared spectroscopy to monitor mycotoxins in corn, wheat, and barley. More specifically, we focus on the Fusarium species and on the main fusariotoxins of deoxynivalenol, zearalenone, and fumonisin B1 and B2. Quantification models are insufficiently precise to satisfy the legal requirements. Sorting models with cutoff levels are the most promising applications.
\end{abstract}

Keywords: NIR; MIR; mycotoxins; Fusarium; infrared spectroscopy

Key Contribution: We have updated a review of the literature dealing with infrared spectroscopy and the detection of fusariotoxins in corn, wheat, and barley. The use of infrared spectroscopic tools to detect and quantify mycotoxins does not provide the requisite regulatory precision, nevertheless, these tools can be used for sorting cereals, be they in or out of risk groups.

\section{Introduction}

As of 2016, wheat, barley, and maize, which are grown for both human and animal consumption, are among the most important cultivated plant species on the planet [1]. These cereals are subject to infection by the cereal pathogen Fusarium, which is a major concern worldwide. A Fusarium infection can cause plant disease and the fungus can produce fusariotoxins, which are small toxic molecules secreted as fungal secondary metabolites onto cereals and are part of the mycotoxin family [2-4]. These mycotoxins have a significant impact not only on public health, but also on agriculture economics and technology by reducing the yield, nutritional quality, and overall quality of the cereals [5-7].

The Food and Agriculture Organization (FAO) estimates that 25\% of the world's food crops are affected by mycotoxin-producing fungi. Faced with this threat, a legal framework is gradually being set up at the global level to set standards defining the maximum acceptable level of mycotoxin in foodstuffs, and enforcing such standards requires methods to detect and quantify mycotoxins [8].

The most widely used methods to monitor mycotoxins are chromatographic and immunological methods, or are based on biosensors [9-13]. Immunological methods, such as ELISA, can detect most of the mycotoxins, but they are mainly used for screening. The main drawbacks are the number of false positives (because of cross-reactivity and matrix-dependence) or false negatives (because of low sensitivity), in comparison with chromatographic methods. Indeed, chromatographic methods can analyze several mycotoxins at a time, with high sensitivity and selectivity, giving accurate toxins contents. Although widely used, these methods are expensive and, by requiring time-consuming 
extraction and clean-up steps, provide results only after a significant time lapse. Moreover, the samples are destroyed by the analysis. Cereal growers therefore require alternative methods that are simple, rapid, and that can be applied in the field, to detect mycotoxins in their products. Infrared spectroscopy has been used for many years for quality control in the food industry. In fact, the quality of cereals can be monitored by infrared spectroscopy by determining the proximate parameters (moisture, protein, oil, etc.). This technique is widely used because it is rapid, nondestructive, requires no chemicals, and is therefore eco-friendly [14].

The versatility of infrared spectrometry has led to its use in multiple applications, including soil chemistry, medicine, biology, agro-food, and cereals, and so forth. Because it probes the interactions between infrared radiation and matter, infrared spectroscopy is an appropriate tool for analyzing raw material, monitoring manufacturing processes, and validating finished products. From a theoretical point of view, this technique has no limits, provided a predictive model may be developed for the given process. The current trend consists of increasing the potential of this technique by developing new chemometric methods to create a tool adapted to a given application [15-17]. We distinguish four types of analyses for cereals: those related to nutritional quality (water, lipids, proteins, carbohydrate content, etc.); biological quality (germinative ability, specific purity, etc.); technological quality, and; sanitary quality (infestation by insects, pesticides, toxins, etc.). The challenge related to the presence of mycotoxins falls into the latter category. Infrared methods have limited sensitivity for contaminants. Furthermore, interpretation of infrared spectra cannot be done without the use of chemometrics, and reliable models necessitate large data set of samples (with their reference values). Despite those limitations, much research has focused on using infrared spectroscopy to monitor and analyze fusariotoxins. Mycotoxins are small molecules (MW = $700 \mathrm{Da})[10,13]$. These toxins are found at very low concentrations, mostly parts per million (ppm), and are toxic at very low levels [13]. In fact, the level of mycotoxins is very low compared with the major seed constituents (protein, starch, etc.). Thus, analytical tools must be to detect such low concentrations; in the range of $\mathrm{ppm}(\mathrm{mg} / \mathrm{mL})$ or a few parts per billion (ppb; $\mathrm{ng} / \mathrm{mL}$ ), and infrared spectroscopy currently is not sufficiently sensitive. However, changes in cereal properties such as protein, carbohydrate, or lipid content or texture are associated with changes in fungal contamination. In fact, a fungal attack damages the tissues, cells, or even molecules, and such damage is reflected in the spectral signature [18]. For example, Shenk and Workman [19] have identified spectral areas of interest related to the presence of fungi in $\mathrm{CH}_{3}, \mathrm{CH}_{2}$, $\mathrm{CONH}_{2}$, amide, starch, and cellulose structures. Mycotoxins are fungal metabolites and, like the molds that synthesize them, their distribution within the silo is heterogeneous. Thus, the sanitary quality of a given sample is not necessarily representative of the sanitary quality of the entire silo [20-22]. That is why some of the research reviewed deals with online infrared analysis, to avoid sampling.

This work reviews the recent research dealing with infrared spectroscopy and the detection of fusariotoxins in corn, wheat, and barley and complements a previous review [23] by summarizing the latest advances made since 2009. It relies on the reviews of McMullin et al. [24], Orina et al. [13], and Min and Cho [25], and emphasizes research involving corn, wheat, and barley.

\section{Infrared Spectroscopy}

Infrared spectroscopy reveals the interaction between infrared electromagnetic radiation $(800-25,000 \mathrm{~nm})$ and chemical bonds $[15,26,27]$. An analysis of the radiation reflected or transmitted by a sample allows one to determine the energy of the molecular overtones and of the vibrations of chemical bonds in the sample. The energy of these vibrations identifies the nature of the chemical bonds, thereby providing information about the functional groups in the molecules.

Mid-infrared spectroscopy ( 2500 to $10,000 \mathrm{~nm}$ ) is widely used in analytical organic chemistry. The near-infrared (NIR) region ( 800 to $2500 \mathrm{~nm}$ or $12,500 \mathrm{~cm}^{-1}$ to $4000 \mathrm{~cm}^{-1}$ ) is less used because it encompasses relatively broad overtones and combinations of $\mathrm{CH}, \mathrm{NH}, \mathrm{OH}$, and $\mathrm{SH}$ groups. The broad overtones and combined bands overlap, resulting in a complex spectrum with an intensity one to two 
orders of magnitude less than the spectral peaks in the mid-infrared. More details are available in the tutorial by Agelet and Hurburgh [28,29].

Interpreting mid-infrared spectra is straightforward because of the specificity of the absorption peaks. Conversely, interpreting NIR spectra is more complex, because they involve superpositions of spectral peaks. It also requires the use of chemometrics, which is the application of mathematical tools to obtain the maximum information possible from chemical data [30].

Developing a model requires calibrating a spectrometer with reference data obtained in the laboratory. These data (protein content, moisture content, etc.) are correlated with the infrared spectra of the samples. A predictive model is developed via five main steps [29]: (1) First, the calibration samples are selected. They must be representative of the samples that will be routinely analyzed once the model is developed and must be analyzed by using a chemical reference method (e.g., high-performance liquid chromatography or gas chromatography mass spectroscopy) [31]. The range of the "analyte" content should be covered by the range of the calibration samples. The samples are generally divided randomly into two sets: a calibration set and a validation set (about $75 \%$ and $25 \%$, respectively) [32,33]; (2) The infrared spectra of the reference samples are then acquired either by reflection- or transmission-mode spectroscopy. In reflection mode, the spectrometer detects the intensity of the light reflected by the sample, whereas in transmission mode, the spectrometer records the intensity of light transmitted through the sample; (3) Mathematical preprocessing is applied to eliminate baseline noise and drifts; (4) A model is developed to establish a correlation between spectral values and reference values; (5) Finally, the model is validated. Once the model is developed and validated, it can be used routinely. In the following paragraphs, we provide more details about this process.

\subsection{Spectral-Data Preprocessing}

Spectral-data preprocessing [29] refers to the mathematical manipulation of raw spectral data and is used to suppress or reduce intensity variations related to factors that should not be considered in the model. The right choice of preprocessing may be critical to the development of the model. Different preprocessing methods are commonly used in infrared spectroscopy: derivative [34,35], smoothing [36], detrending (which is often used after a standard normal variation [35,37]), multiplicative scatter correction [38], and so on. Derivatives are most commonly used in mycotoxin studies [39-42].

\subsection{Types of Regression Used to Develop Prediction Model}

Two main chemometric methods are used in infrared spectroscopy: classification methods, and regression methods [43].

Classification models allow us to classify the samples into groups, called classes, based on their distinguishing spectral features. Two approaches to classification exist: supervised and unsupervised. In unsupervised classification, the spectral similarities and dissimilarities of the samples are used to create groups, whereas in supervised classification, group membership is defined at the beginning of the modeling (discriminant analysis) [30,44].

Regression methods are used to link spectra to chemical values and include linear and nonlinear methods. The three best-known linear-regression methods are multiple linear regression, principal component regression, and partial least squares regression (PLS). PLS is the most widely used method in infrared spectroscopy [29], and particularly in works concerning mycotoxins [41,45-50]. It was introduced by Wold in 1966 and popularized by Martens in the early 1980s [51]. This method consists of establishing a regression of the variable to be predicted as a function of latent variables, which are linear combinations of the original predictive variables (i.e., wavelengths). They are determined by considering the original variables and the variable to be predicted and minimizing the sum of the squares of the residuals [44]. The most used nonlinear method is the artificial neural network (ANN), which was developed in the late 1980s and early 1990s [52]. The principle of ANNs is analogous to that of biological neurons; it consists of connected neurons, each of which carries out a single task and communicates the result to one or more neuron by applying precise rules [44]. 


\subsection{Validation and Performance of Model}

The model's ability to accurately predict the characteristics of new samples is ideally determined by applying the model to a set of samples that was not used to develop the model. Such a procedure constitutes an external validation of a test set. Sometimes the dataset is not sufficiently large to subdivide it into two sets, so the cross-validation method is used.

The performance of a model is evaluated mainly by the coefficient of determination $r^{2}$ and the standard error of calibration (SEC) (see Table 1). The latter is based on the residuals, that is, the differences between the predicted values and the actual values of the $n$ samples of the calibration set. The residuals represent the information contained in the data of the $n$ reference samples which are not explained by the model [36]. The full validation of the model involves the study of the validation set. The samples in this set are used to test the predictive quality of the model by calculating the standard error of prediction (SEP) the prediction deviation, and the root mean square error of prediction (RMSEP). For cross-validation, the population of the calibration set is divided into $t$ subgroups. A calibration equation is determined based on $(t-1)$ groups and then validated on the remaining group. This operation is resumed by permutation over the other subgroups. The calculated standard deviation is the standard error of cross-validation (SECV), which is often optimistic [29]. The last performance metric to report is the relative prediction determinant (RPD), which represents the ability of the model to predict unknown samples, considering the variability of the training set. Williams [53] provides RPD thresholds to give an idea of the potential for applying calibrations to new samples: if the RPD is less than 2.3, the model cannot be used, whereas if it exceeds 8 , the model can be used without hesitation.

Table 1. Performance Criteria for Validated Model [29,36,54].

\begin{tabular}{|c|c|c|}
\hline \multicolumn{3}{|c|}{$\begin{array}{l}k=\text { number of factors, } y_{i}=n \text { measured values, } \hat{y}_{i}=n \text { predicted values } \\
\qquad \sum d_{i}=\sum_{i=1}^{n}\left(y_{i}-\hat{y}_{i}\right) \text { et } \sum x=\sum_{i=1}^{n} x\end{array}$} \\
\hline$r^{2}$ & Determination coefficient & $r^{2}=\frac{\sum\left(\hat{y}_{i}-\bar{y}\right)^{2}}{\sum\left(y_{i}-\bar{y}\right)^{2}}$ \\
\hline Bias (same units as reference value) & Bias & Bias $=\frac{\sum d_{i}}{n}$ \\
\hline SEC (same units as reference value) & Standard Error of Calibration & $S E C=\frac{\sum\left(d_{i}\right)^{2}}{n-k-1}$ \\
\hline SEPc (same units as reference value) & $\begin{array}{l}\text { Standard Error of Prediction } \\
\text { (corrected by the bias) }\end{array}$ & $S E P_{c}=\sqrt{\frac{\left(d_{i}-\text { bias }\right)}{n-1}}$ \\
\hline RMSEP (same units as reference value) & Root Mean Square Error of Prediction & $R M S E P=\sqrt{\frac{\sum d_{i}^{2}}{n}}$ \\
\hline RPD & Ratio of Performance to Deviation & $R P D=\frac{S t d E r r o r_{r e f}}{S E P_{c}}$ \\
\hline
\end{tabular}

The largest $r^{2}$ corresponds to the best model. In addition, the best model has the smallest $S E P_{\mathcal{C}}[29,54]$.

The brief outline above describes a method to develop a predictive model based on infrared spectroscopy. These instructions are valid regardless of the type of spectrometer used [29]. In general, a spectrometer is made of several parts: a light source; a wavelength-selection system; a signal-detection system; a signal-processing system, and; an apparatus for positioning the sample [55].

\section{Using Infrared Spectroscopy to Quantify Fusariotoxins in Corn, Wheat, and Barley}

A tool to quantify mycotoxins in these cereals is of interest only if it is sufficiently sensitive and specific with respect to the maximum permissible levels for mycotoxins. Toxins should be detected, but with a low false-negative rate, which minimizes the risk of cereal contamination in the food chain [21].

The first applications of infrared spectroscopy to the analysis of microorganisms date from the 1950s [56]. In the 1980s, Fraenkel et al. [57] and Davies et al. [58] published their first work on the use of NIR spectroscopy to detect fungal contamination. Various studies have been carried out since the 1990s [23]. This work compiles the studies carried out since 2009 (Table 2). 
Table 2. Summary of studies of infrared spectroscopy applied to quantification of mycotoxins in barley, corn, and wheat. Deoxynivalenol (DON); Zearalenone (ZON); partial least squares regression (PLS); near-infrared (NIR); standard error of cross-validation (SECV); linear discriminant analysis (LDA); liquid chromatography and mass spectrometry (LC-MSMS); Fusarium-damaged kernels (FDKs).

\begin{tabular}{|c|c|c|c|c|}
\hline Mycotoxin or Fungi & $\begin{array}{c}\text { Crop/Number of } \\
\text { Samples/Sample Preparation }\end{array}$ & Spectral Range & Performance and Characteristic Wavelengths & Reference \\
\hline DON & $\begin{array}{l}\text { Wheat: } 30 \text { kernels artificially } \\
\text { inoculated/Single kernel }\end{array}$ & $\begin{array}{c}\mathrm{NIR} \\
950-1650 \mathrm{~nm}\end{array}$ & $\begin{array}{l}\text { DON band absorption: } 1408 \mathrm{~nm}, 1904 \mathrm{~nm}, 1919 \mathrm{~nm} \\
\text { Differences at } 1204 \mathrm{~nm}, 1365 \mathrm{~nm} \text { and } 1700 \mathrm{~nm} \text {, attributed to changes in food } \\
\text { reserves such as starches, proteins, and lipids. }\end{array}$ & Peiris et al. (2009) [39] \\
\hline Fusarium-damaged kernels & $\begin{array}{l}\text { Corn: } 600 \text { spectra in training set and } \\
300 \text { spectra in test set/Single kernel (spectra } \\
\text { collected on germ side and on other side of grain) }\end{array}$ & $\begin{array}{c}\mathrm{NIR} \\
400-2498 \mathrm{~nm}\end{array}$ & $\begin{array}{l}\text { SIMCA classifier or Probabilistic Neural Network: best results: healthy grains } \\
\text { well classified = 99.3\%, } 98.7 \% \text { for infected grains } \\
\text { Grain position (germ side or other side) is a significant factor for } \\
\text { disease detection }\end{array}$ & $\begin{array}{l}\text { Draganova et al. } \\
\quad(2010)[59]\end{array}$ \\
\hline DON-Fusarium-damaged kernels & Wheat/single kernels & & Prediction of DON levels in kernels having > $60 \mathrm{ppm}$ DON : sorting & Peiris et al. (2010) [40] \\
\hline DON-ZON & $\begin{array}{l}\text { Wheat: } 196 \text { samples for DON, } 120 \text { samples for } \\
\text { ZON/Whole and milled grains }\end{array}$ & $\begin{array}{c}\mathrm{NIR} \\
400-2500 \mathrm{~nm}\end{array}$ & $\begin{array}{l}\text { Whole kernels: DON(LC-MSMS)-DON(IR): } r^{2}=0.89 \text { SECV }=612.05 \mu \mathrm{g} \mathrm{kg} \mathrm{kg}^{-1} \\
\text { Milled kernels: DON(LC-MSMS)-DON(IR): } r^{2}=0.91 \text { SECV }=578.33 \mu \mathrm{g} \mathrm{kg} \\
\text { Whole kernels: ZON(LC-MSMS)-ZON(IR): } r^{2}=0.86 \text { SECV }=254.29 \mu \mathrm{\mu g} \mathrm{kg}^{-1} \\
\text { Milled kernels: ZON(LC-MSMS)-ZON(IR): } r^{2}=0.87 \text { SECV }=231.85 \mu \mathrm{g} \mathrm{kg}\end{array}$ & Tibola et al. (2010) [45] \\
\hline $\begin{array}{l}\text { Aspergillus flavus, Bipolaris zeicola, } \\
\text { Diplodia maydis, Fusarium oxysporum, } \\
\text { Penicillium oxalicum, Penicillium } \\
\text { funiculosum, Trichoderma harzianum }\end{array}$ & $\begin{array}{c}\text { Corn: } 864 \text { inoculated single kernels } \\
0 \text { to } 100 \% \text { infected }\end{array}$ & $\begin{array}{c}\mathrm{NIR} \\
904-1685 \mathrm{~nm}\end{array}$ & $\begin{array}{l}\text { All levels of infection: } \\
\text { LDA accuracy: } 89 \% \text { on control, } 79 \% \text { on infected } \\
\text { MLP accuracy: } 84 \% \text { on control, } 83 \% \text { on infected } \\
\text { False negatives: caused by inclusion of asymptomatic kernels }\end{array}$ & $\begin{array}{l}\text { Tallada et al. } \\
\text { (2011) [60] }\end{array}$ \\
\hline DON & $\begin{array}{l}399 \text { wheat samples - whole grains } \\
\text { artificially infected }\end{array}$ & $\begin{array}{c}\text { FT-NIR } \\
10,000-400 \mathrm{~cm}^{-1}\end{array}$ & $\begin{array}{l}\text { Reference }=\text { ELISA } \\
\text { PLS } \\
0<\text { DON }<92 \mathrm{mg} / \mathrm{kg}: r=0.94 ; \mathrm{SEP}=6.23 \mathrm{mg} / \mathrm{kg} ; \mathrm{RPD}=3.02 \\
0<\mathrm{DON}<30 \mathrm{mg} / \mathrm{kg}: r=0.92 ; \mathrm{SEP}=2.43 \mathrm{mg} / \mathrm{kg} ; \mathrm{RPD}=2.60 \\
\text { PLS-DA: improvement from the best PLS model: } r=0.92, \mathrm{SEP}=2.35 \mathrm{mg} / \mathrm{kg} \\
\text { Identification of two spectral regions }(1390-1770 \mathrm{~nm} \text { and } 1880-2070 \mathrm{~nm})\end{array}$ & $\begin{array}{l}\text { Dvoracek et al. } \\
\quad(2012)[46]\end{array}$ \\
\hline Fumonisins B1 and B2 & Corn milled grains: 168 samples & $\begin{array}{c}\text { FT-NIR } \\
650-2500 \mathrm{~nm}\end{array}$ & PLS: $r^{2}=0.964, \mathrm{SEC}=0.433 \mathrm{mg} / \mathrm{kg}, \mathrm{SEP}=0.839 \mathrm{mg} / \mathrm{kg}, \mathrm{RPD}=1.2$ & $\begin{array}{l}\text { Gaspardo et al. } \\
\text { (2012) [47] }\end{array}$ \\
\hline DON-Fusarium-damaged kernels & $\begin{array}{l}\text { Wheat } \\
\text { Grains were dissected, and each section was } \\
\text { pressed to the ATR diamond crystal }\end{array}$ & $\begin{array}{c}\text { FT-MIR } \\
4000-380 \mathrm{~cm}^{-1}\end{array}$ & $\begin{array}{l}\text { Marked differences in absorption patterns between sound and fusarium } \\
\text { damaged pericarp and germ spectra: shift } 1035 \mathrm{~cm}^{-1} \text { and increased } \\
\text { absorptions at 1160,1203,1313, and } 1375 \mathrm{~cm}^{-1} \text { (influence of DON and fungi } \\
\text { on wheat matrix) }\end{array}$ & Peiris et al. (2012) [61] \\
\hline DON-Fusarium-damaged kernels & $\begin{array}{c}\text { Wheat } \\
\text { Whole grains? }\end{array}$ & $\begin{array}{c}\mathrm{NIR} \\
950-1650 \mathrm{~nm}\end{array}$ & $\begin{array}{l}\text { FDK-FDKNIR: } r=0.70(2010) \text { and } 0.73(2011) \\
\text { DON-DONNIR: } r=0.56(2010) \text { and } 0.63(2011) \\
\text { Differences due to changes in carbohydrate, lipid, protein, and DON levels, } \\
\text { and physical properties of the kernels }\end{array}$ & Balut et al. (2013) [62] \\
\hline DON-NIV & $\begin{array}{c}\text { Barley: } 200 \text { spectra-cross-validation } \\
\text { Milled grains }\end{array}$ & $\begin{array}{c}\text { NIR } \\
12,000-4000 \mathrm{~cm}^{-1}\end{array}$ & $\begin{array}{l}\text { DON-DONNIR: } r=0.875 \text { rcrossval }=0.513 \\
\text { RMSEC }=0.147 \mathrm{e} 3, \text { RMSECV }=0.268 \text { e3RMEP }=0.399 \mathrm{e} 3 \\
\text { NIV-NIVNIR: } r=0.828 \text { rcrossval }=0.744 \text { RMSEC }=0.310 \mathrm{e} 3 \text { RMSECV }=0.371 \mathrm{e} 3 \\
\text { RMSEP }=0.433 \mathrm{e} 3 \\
\text { models applicable only for detection of highly contaminated grain lots }\end{array}$ & $\begin{array}{c}\text { Bezdekova and } \\
\text { Bradacova (2013) [41] }\end{array}$ \\
\hline
\end{tabular}


Table 2. Cont

\begin{tabular}{|c|c|c|c|c|}
\hline Mycotoxin or Fungi & $\begin{array}{c}\text { Crop/Number of } \\
\text { Samples/Sample Preparation }\end{array}$ & Spectral Range & Performance and Characteristic Wavelengths & Reference \\
\hline Fumonisins & $\begin{array}{c}\text { Corn } \\
\text { Milled grains }\end{array}$ & $\begin{array}{l}\text { FT-NIR } \\
650-2500 \mathrm{~nm}\end{array}$ & $\begin{array}{l}\text { PLS HPLC } \\
r^{2}=0.995 ; \mathrm{SEC}=0.232, r^{2}=0.908 ; \mathrm{SEP}=0.933 \\
\text { Evaluation of the screening and classification ability with thresholds } \\
\text { corresponding to legal limits }\end{array}$ & $\begin{array}{l}\text { Della Riccia and } \\
\text { Del Zotto (2013) [48] }\end{array}$ \\
\hline DON & $\begin{array}{l}\text { Wheat } 464 \text { samples } \\
\text { Milled grains }\end{array}$ & $\begin{array}{c}\text { FT-NIR } \\
10,000-4000 \mathrm{~cm}^{-1}\end{array}$ & $\begin{array}{l}\text { PLS } \\
\text { traces }<\text { DON }<16,000 \mu g / \mathrm{kg} \\
\text { RMSEP }=1977 \mu \mathrm{\mu g} / \mathrm{kg} \geq \text { poor ability } \\
\text { LDA } \\
3 \text { classes }(\text { DON } \leq 1000 \mu \mathrm{gg} / \mathrm{kg} \text { ) }-1000<\text { DON }<2500 \mu \mathrm{g} / \mathrm{kg}-\mathrm{DON}>2000 \mu \mathrm{g} / \mathrm{kg} \text { ) } \\
75-90 \% \text { accuracy }\end{array}$ & $\begin{array}{l}\text { De Girolamo et al. } \\
\text { (2014) [49] }\end{array}$ \\
\hline DON-Fusarium-damaged kernels & Wheat/Single kernel & $\begin{array}{c}\text { NIR } \\
1100-1700 \mathrm{~nm}\end{array}$ & $\begin{array}{l}\text { Creation of several lots of varying quality (FDK et DON), based on the } \\
\text { crude protein. }\end{array}$ & $\begin{array}{l}\text { Kautzman et al. } \\
\quad(2015)[64]\end{array}$ \\
\hline DON and fumonisins & $\begin{array}{l}381 \text { samples for DON } \\
511 \text { samples for FUM/Whole grains }\end{array}$ & NIR $400-2498 \mathrm{~nm}$ & $\begin{array}{l}\text { Reference: HPLC MS } \\
\text { discriminant analysis } \\
\text { Accuracies from } 60 \text { to } 84 \% \text { with external validation }\end{array}$ & $\begin{array}{l}\text { Levasseur-Garcia and } \\
\text { Kleiber (2015) [50] }\end{array}$ \\
\hline DON-ZON & $\begin{array}{c}\text { Corn artificially inoculated } \\
9<\text { DON }<920 \mathrm{mg} / \mathrm{kg} \\
\text { Milled grains }\end{array}$ & NIR & $r(\mathrm{DON} / \mathrm{DON}$ immunotest $)=0.80$ & $\begin{array}{l}\text { Miedaner et al. } \\
\text { (2015) [65] }\end{array}$ \\
\hline DON & $\begin{array}{l}110 \text { corn samples (naturally and } \\
\text { artificially infected) } \\
\text { Milled grains-100-250 } \mu \mathrm{m} \text { sieve fraction }\end{array}$ & $\begin{array}{c}\text { MIR } \\
4000-575 \mathrm{~cm}^{-1}\end{array}$ & $\begin{array}{l}\text { Carbohydrate }\left(1000 \mathrm{~cm}^{-1}\right) \text { and protein }\left(1500 \mathrm{~cm}^{-1}\right) \text {-related vibrations } \geq \\
\text { spectral window used for modelling: } 1800-800 \mathrm{~cm}^{-1} \\
\text { Classification threshold (cross-validation): } \\
1750 \mu \mathrm{\mu g} / \mathrm{kg} \text { : overall classification accuracy }=79 \% \\
500 \mu \mathrm{g} / \mathrm{kg} \text { : overall classification accuracy }=85 \%\end{array}$ & Kos et al. (2016) [66] \\
\hline DON & $\begin{array}{l}\text { Corn (24 samples), wheat } \\
\text { Grains extracts }\end{array}$ & $\begin{array}{c}\text { MIR } \\
1820-1560 \mathrm{~cm}^{-1}\end{array}$ & $\begin{array}{l}\text { Alterations of the sample matrix caused by fungal infection: } 1655,1710 \text {, } \\
1740 \mathrm{~cm}^{-1} \geq \text { Classification of grain }\end{array}$ & Sieger et al. (2017) [67] \\
\hline Fumonisins & $\begin{array}{l}\text { Corn (453 grains) } \\
\text { Single kernels }\end{array}$ & Multispectral VIS-NIR & $\begin{array}{l}\text { First round: } 470,527,624,850,880,910,940,1070 \mathrm{~nm} \\
\text { second round: } 910,940,970,1050,1070,1200,1300,1450,1550 \mathrm{~nm} \\
\text { LDA } \geq \text { maximum cross-validation sensitivity }(77 \%) \text { and sensibility }(83 \%) \text { to } \\
\text { reject corn kernels with fumonisin }>1000 \mathrm{ng} / \mathrm{g}\end{array}$ & $\begin{array}{l}\text { Stasiewicz et al. } \\
\quad(2017)[42]\end{array}$ \\
\hline
\end{tabular}


The referenced studies target deoxynivalenol (14/19), fumonisins (4/19), zearalenone (2/19), fungi $(2 / 19)$ and nivalenol (1/19). Most of the work therefore concerns DON and Fusarium head blight. This work includes quantification models or grading models in batches of toxin levels. For DON, quantification models have variable performances (Tibola et al., 2010; Dvoracek et al., 2012; Balut et al., 2013; Bezdekova and Bradacova, 2013; De Girolamo et al., 2014; Jin et al., 2014, Miedaner et al., 2015). Tibola et al. (2010) [45] worked on wheat grains naturally contaminated with Fusarium graminearum and DON (196 samples). The wheat samples were analyzed as whole grains (125 g), and then crushed and sieved to obtain diameters less than $1.0 \mathrm{~mm}$. Reference analyses were done by combined liquid chromatography and mass spectrometry (LC-MSMS). They developed a model for predicting DON in whole-grain (crushed) grades with $r^{2}=0.89$ (0.91). Dvoracek et al. (2012) [46] worked on whole-wheat samples to determine their DON content. They conclude that the combination of two tools, a discriminant analysis (DA) followed by a PLS regression, improves the accuracy of the models. The quality of the models depends strongly on the choice of the class limits, in terms of DON contents. Balut et al. (2013) investigated ways to predict DON and FKD levels in wheat [62]. The correlation between Fusarium-damaged kernels (FDKs) and FDKs predicted by NIR spectroscopy is 0.7 and 0.73 , respectively, and the correlation between DON and DON predicted by NIR spectroscopy is 0.56 and 0.63 for the years 2010 and 2011, respectively. Bezdekova and Bradacova [41] applied FT-NIR to barley to determine DON and NIV content. Barley was not only inoculated artificially, but also naturally contaminated. De Girolamo et al. [49] used FT-NIR to study DON in wheat samples. The authors propose classification models that yield an interesting percent of correct classification (75-90\%). Jin et al. (2014) [63] conducted a similar study with artificially inoculated wheat samples. The authors found a significant correlation between the GC-MS DON levels and the predictions by their infrared model $\left(r^{2}=0.46, p<0.001\right)$, as well as a significant correlation between the number of FDKs evaluated visually and estimated by infrared spectroscopy $\left(r^{2}=0.52, p<0.001\right)$. The authors explain that a bias exists in this study because the DON content determined by GC-MS was for bulk samples, whereas the spectra were collected from individual grains. Miedaner et al. [65] worked with samples of corn artificially inoculated with Fusarium graminearum. They predicted DON levels by using NIR spectra and obtained $r=0.80$. No information is given on model errors.

DON assay quantification models are poor at predicting a specific grade, especially with respect to regulatory grades. However, these models can be used to classify grain lots according to a level of toxin contamination $[40,41,49,64,66]$. Peiris et al. $(2009,2010)[39,40]$ used a grain-to-grain method to identify wheat grains infected with Fusarium and to predict DON levels. Their findings indicate that it is possible to predict the DON concentration when it exceeds 60 ppm $[39,40]$. Kautzman et al. [64] developed a model based on an indirect indication of the presence of mycotoxins; namely, the crude protein level. By sorting grains based on this index and classifying them into different fractions, they reduced the DON content and the percent of FDKs (for the best batches). Levasseur-Garcia and Kleiber (2015) [50] proposed different models for identifying maize grain contaminated with DON or with fumonisins (FUM). Based on the European detection limits, the models provide correct identification at a rate of $60 \%$ and $84 \%$, respectively, in external validation. Kos et al. [66] worked on DON in corn samples. They used a bagged decision tree classification, focusing on a spectral window corresponding to $800-1800 \mathrm{~cm}^{-1}$. This window contains information related to carbohydrates and proteins. The rate of proper cross-validation ranking varies between $79 \%$ and $85 \%$, depending on the DON limit used to create the classes. Sieger et al. [67] proposed a new on-site mycotoxin analysis by combining mid-infrared tunable quantum cascade laser spectroscopy (QCL) with GaAs/AlGaAs thin-film waveguides to classify deoxynivalenol-contaminated maize and wheat samples, and aflatoxin $\mathrm{B}_{1}$ affected peanuts at European Union (EU) regulatory limits of $1250 \mu \mathrm{g} \mathrm{kg} \mathrm{k}^{-1}$ and $8 \mu \mathrm{g} \mathrm{kg} \mathrm{k}^{-1}$, respectively. Very few techniques are available for on-site analysis. This recent work therefore offers a very interesting opportunity for field use, thanks to miniaturization [68].

The work on fumonisins draws the same conclusions [42,47,48,50]. The best models have screening ability with thresholds corresponding to legal limits. Gaspardo et al. [47] propose a model that uses 
Fourier-transform NIR (FT-NIR) spectroscopy to predict FB1 and FB2 levels in corn samples. The model has a low RPD value (1.2), even for screening purposes [49,69]. Della Riccia and Del Zotto [48] developed a PLS model to predict the fumonisin levels of maize samples. They propose predictive models that can be used for classification, emphasizing the $4 \mathrm{mg} / \mathrm{kg}$ threshold stipulated by EU regulation. Stasiewicz et al. [42] tested a low-cost multispectral tool, combining both the visible and the NIR to sort fumonisin-contaminated maize grains. By using two-stage sorting, they spread the grains with a success percent close to $80 \%$.

The work to identify levels of infection by several fungi have good performances investigated Fusarium-infected corn kernels [59]. They combined visible and NIR spectroscopy and used various classification approaches such as the soft independent modeling of class analogy (SIMCA) and neural networks. The spectrum of each grain was collected from both the germ side and the opposite side, with the best results coming from the side opposite the germ. Healthy and infected grains are properly graded at a rate of $99.3 \%$ and $98.7 \%$, respectively. These results were obtained from a test set. Tallada et al. (2011) applied NIR spectroscopy (904-1685 nm) to single kernels to identify maize grain infected to varying degree with eight fungal strains. They used linear discriminant analysis (LDA) or ANNs. The objective was to discriminate between healthy and diseased grains. The ANN (LDA) model correctly discriminated $84 \%$ (89\%) of healthy grains and $83 \%$ (79\%) of infected grains [60].

Moreover, as mycotoxins and fungi cannot be directly detected in the grain matrix, because of the lack of sensitivity of infrared devices, indirect information of contamination is used in models. The contamination is assessed by detecting alterations of the grains. Indeed, different authors have identified spectral zones that indicate grain alterations due to fungal attack or to the presence of mycotoxins $[40,66,70,71]$ : the changes are related to carbohydrate content $\left(900-1200 \mathrm{~cm}^{-1}\right)$ and proteins (amide bands I and II, 1200-1750 $\mathrm{cm}^{-1}$ ).

Another point concerns methods for the simultaneous analysis of several of mycotoxins [72]. This is well achieved by LC-MS/MS (liquid chromatography with tandem mass spectrometry), but in the current state of research, no studies based on an infrared tool report a multi-toxin model. This is probably a research direction for the years to come.

In a global way, the use of the infrared tool in toxin detection is an integral part of quality control of agricultural products, and monitoring of the resources. Mycotoxins could be part of a multi-parametric analysis of cereals, in seconds, with no sample preparation [73].

\section{Conclusions}

In recent years, several studies have investigated the use of spectroscopic methods to detect mycotoxins in grains. These methods are fast, inexpensive, nondestructive, and, once the model is developed, require little sample preparation and few well-trained technicians.

However, the use of infrared spectroscopic tools to detect and quantify mycotoxins does not provide the requisite regulatory precision [24]. The large standard errors show that, because of the sensitivity limits of the devices, these quantization models are insufficiently precise to satisfy the legal requirements $[13,24,74]$.

Thus, mycotoxin detection capabilities need to be improved. Hopefully, the recent and continuous improvements in mathematical preprocessing will increase the sensitivity and precision of the models. Note that these tools can be still used for sorting food products, be they in or out of risk groups [14,75-77], which would allow "distinguishing, sorting, screening and monitoring" with cutoff levels [78]. Because mycotoxin-contaminated products are not evenly distributed within a given lot, large volumes must be scanned to increase the margin of safety. The most promising applications might be in-line single-kernel analyses, which would promote the production of commercial foodstuffs (feed, food, baby food) with optimal quality from any grade of raw material. All these methods detect a change in the grains related to the presence of the fungus $[23,64]$.

This review thus highlights some of the developments over the past eight years in the detection of fusariotoxins to give an overview of the current state of the art for applying infrared spectroscopic 
methods to this field and to outline the most promising methods. Future work will require working on masked mycotoxins, whose importance is discussed in the review of Dall'Asta and Battilani [79]. The use of other spectroscopic techniques should also be developed; for example, Raman spectroscopy [80] or hyperspectral imaging techniques [81-84].

Conflicts of Interest: The author declares no conflict of interest.

$\begin{array}{ll}\text { Abbreviations } \\ \text { ANN } & \text { Artificial neural networks } \\ \text { ATR } & \text { Attenuated total reflection } \\ \text { DA } & \text { Discriminant analysis } \\ \text { DON } & \text { Deoxynivalenol } \\ \text { FDK } & \text { Fusarium damaged kernel } \\ \text { FT-NIR } & \text { Fourier transform near infrared spectroscopy } \\ \text { FUM } & \text { Fumonisins } \\ \text { LC-MS } & \text { Liquid chromatography-mass spectrometry } \\ \text { KNN } & \text { K-nearest neighbor classification } \\ \text { LDA } & \text { Linear discriminant analysis } \\ \text { MIR } & \text { Mid-infrared wavelength } \\ \text { MPL } & \text { Multilayer perceptron neural network } \\ \text { NIR } & \text { Near-infrared wavelength } \\ \text { PCA } & \text { Principal component analysis } \\ \text { PCR } & \text { Polymerase chain reaction } \\ \text { PLS } & \text { Partial least squares regression } \\ \text { PLSDA } & \text { Partial least squares discriminant analysis } \\ \text { SVM } & \text { Support vector machines } \\ \text { VIS } & \text { Visible wavelength } \\ \text { ZON } & \text { Zearalenone } \\ & \end{array}$

\section{References}

1. Organisation for Economic Co-operation and Development/Food and Agriculture Organization (OECD/FAO). Perspectives Agricoles de L'Ocde et de la Fao (Édition 2016), Statistiques Agricoles de L'Ocde (Database); OECD: Paris, France; FAO: Rome, Italy, 2016.

2. Gelderblom, W.C.; Jaskiewicz, K.; Marasas, W.F.; Thiel, P.G.; Horak, R.M.; Vleggaar, R.; Kriek, N.P. Fumonisins-Novel mycotoxins with cancer-promoting activity produced by fusarium moniliforme. Appl. Environ. Microbiol. 1988, 54, 1806-1811. [PubMed]

3. Richard, J.L. Some major mycotoxins and their mycotoxicoses-An overview. Int. J. Food Microbiol. 2007, 119, 3-10. [CrossRef] [PubMed]

4. Turner, N.W.; Bramhmbhatt, H.; Szabo-Vezse, M.; Poma, A.; Coker, R.; Piletsky, S.A. Analytical methods for determination of mycotoxins: An update (2009-2014). Anal. Chim. Acta 2015, 901, 12-33. [CrossRef] [PubMed]

5. McMullen, M.; Jones, R.; Gallenberg, D. Scab of wheat and barley: A re-emerging disease of devastating impact. Plant Dis. 1997, 81, 1340-1348. [CrossRef]

6. Charmley, L.L.; Trenholm, H.L.; Prelusky, D.B.; Rosenberg, A. Economic losses and decontamination. Nat. Toxins 2006, 3, 199-203. [CrossRef]

7. Dohlman, E. Mycotoxin hazards and regulations: Impacts on food and animal feed crop trade. In International Trade and Food Safety: Economic Theory and Case Studies; Buzby, J., Ed.; Agricultural Economic Report 828; USDA: Washington, DC, USA, 2003.

8. Rasch, C.; Kumke, M.; Löhmannsröben, H.-G. Sensing of mycotoxin producing fungi in the processing of grains. Food Bioprocess Technol. 2010, 3, 908-916. [CrossRef] 
9. Berthiller, F.; Schuhmacher, R.; Buttinger, G.; Krska, R. Rapid simultaneous determination of major type aand $b$-trichothecenes as well as zearalenone in maize by high performance liquid chromatography-tandem mass spectrometry. J. Chromatogr. A 2005, 1062, 209-216. [CrossRef] [PubMed]

10. Turner, N.W.; Subrahmanyam, S.; Piletsky, S.A. Analytical methods for determination of mycotoxins: A review. Anal. Chim. Acta 2009, 632, 168-180. [CrossRef] [PubMed]

11. Pereira, V.L.; Fernandes, J.O.; Cunha, S.C. Mycotoxins in cereals and related foodstuffs: A review on occurrence and recent methods of analysis. Trends Food Sci. Technol. 2014, 36, 96-136. [CrossRef]

12. Bueno, D.; Istamboulie, G.; Muñoz, R.; Marty, J.L. Determination of mycotoxins in food: A review of bioanalytical to analytical methods. Appl. Spectrosc. Rev. 2015, 50, 728-774. [CrossRef]

13. Orina, I.; Manley, M.; Williams, P.J. Non-destructive techniques for the detection of fungal infection in cereal grains. Food Res. Int. 2017, 100, 74-86. [CrossRef] [PubMed]

14. Teye, E.; Huang, X.-Y.; Afoakwa, N. Review on the potential use of near infrared spectroscopy (nirs) for the measurement of chemical residues in food. Am. J. Food Sci. Technol. 2013, 1, 1-8.

15. Osborne, B.; Fearn, T.; Hindle, P.H. Practical Nir Spectroscopy with Applications in Food and Beverage Analysis, 2nd ed.; Addison-Wesley Longman Ltd.: Harlow, UK, 1993; p. 227.

16. Mahaut, B. Near infrared spectrometry as a tool for grading cereals. Photoniques 2008, 34, 60-63.

17. Alander, J.T.; Bochko, V.; Martinkauppi, B.; Saranwong, S.; Mantere, T. A review of optical nondestructive visual and near-infrared methods for food quality and safety. Int. J. Spectrosc. 2013, 2013, 36. [CrossRef]

18. Bauriegel, E.; Giebel, A.; Geyer, M.; Schmidt, U.; Herppich, W.B. Early detection of fusarium infection in wheat using hyper-spectral imaging. Comput. Electron. Agric. 2011, 75, 304-312. [CrossRef]

19. Shenk, J.S.; Workman, J.J., Jr.; Westerhaus, M.O. Application of nir spectroscopy to agricultural products. In Handbook of Near-Infrared Analysis, 2nd ed.; CRC Press: Boca Raton, FL, USA, 2001.

20. Whitaker, T.; Slate, A.; Adams, J.; Birmingham, T.; Giesbrecht, F. Comparing the performance of sampling plans that use a single regulatory limit based upon total aflatoxins to sampling plans that use dual limits based upon b1 and total aflatoxins. World Mycotoxin J. 2010, 3, 35-44. [CrossRef]

21. Cheli, F.; Campagnoli, A.; Dell'Orto, V. Fungal populations and mycotoxins in silages: From occurrence to analysis. Anim. Feed Sci. Technol. 2013, 183, 1-16. [CrossRef]

22. Fleurat-Lessard, F. Integrated management of the risks of stored grain spoilage by seedborne fungi and contamination by storage mould mycotoxins-An update. J. Stored Prod. Res. 2017, 71, 22-40. [CrossRef]

23. Levasseur-Garcia, C. Infrared spectroscopy applied to identification and detection of microorganisms and their metabolites on cereals (corn, wheat, and barley). In Agricultural Science; Aflakpui, D.G., Ed.; InTech: Rijeka, Croatia, 2012; pp. 185-196.

24. McMullin, D.; Mizaikoff, B.; Krska, R. Advancements in ir spectroscopic approaches for the determination of fungal derived contaminations in food crops. Anal. Bioanal. Chem. 2015, 407, 653-660. [CrossRef] [PubMed]

25. Min, H.; Cho, B.-K. Spectroscopic techniques for nondestructive detection of fungi and mycotoxins in agricultural materials: A review. J. Biosyst. Eng. 2015, 40, 67-77. [CrossRef]

26. Campbell, N.A. Biology, 3rd ed.; De Boeck Université: Bruxelles, Belgium, 1995; p. 1190.

27. Ma, G.; Allen, H.C. Handbook of Spectroscopy; Guunter Gauglitz and Tuan Vo-Dinh: Weinheim, Germany, 2003; Volumes 1 and 2, p. 1168.

28. Burns, D.A.; Ciurczak, E.W. Handbook of Near-Infrared Analysis, Revised and Expanded, 3rd ed.; Marcel Dekker Inc.: New York, NY, USA, 2007.

29. Agelet, L.E.; Hurburgh, C.R. A tutorial on near infrared spectroscopy and its calibration. Crit. Rev. Anal. Chem. 2010, 40, 246-260. [CrossRef]

30. Massart, D.L.; Vandeginste, B.G.; Buydens, L.M.C.; Lewi, P.J.; Smeyers-Verbeke, J.; Jong, S.D. Handbook of Chemometrics and Qualimetrics: Part A; Elsevier Science Inc.: New York, NY, USA, 1997; p. 867.

31. Sun, D.-W. Infrared Spectroscopy for Food Quality Analysis and Control; Sun, D.W., Ed.; National University of Ireland: Dublin, Ireland; Academic Press: Cambridge, MA, USA; Elsevier Science: New York, NY, USA, 2009; p. 424.

32. Roggo, Y.; Chalus, P.; Maurer, L.; Lema-Martinez, C.; Edmond, A.; Jent, N. A review of near infrared spectroscopy and chemometrics in pharmaceutical technologies. J. Pharm. Biomed. Anal. 2007, 44, 683-700. [CrossRef] [PubMed]

33. Fearn, T. Chemometrics: An enabling tool for nir. NIR News 2005, 16, 17-19. [CrossRef] 
34. Hurschka, E.R. Data analysis: Wavelength selection methods. In Near-Infrared Technology in the Agricultural and Food Industries; Williams, P.C., Norris, K.H., Eds.; American Association of Cereal Chemists: St. Paul, MN, USA, 1987; pp. 35-53.

35. Luypaert, J.; Heuerding, S.; de Jong, S.; Massart, D.L. An evaluation of direct orthogonal signal correction and other preprocessing methods for the classification of clinical study lots of a dermatological cream. J. Pharm. Biomed. Anal. 2002, 30, 453-466. [CrossRef]

36. Bertrand, D. La spectroscopie proche infrarouge et ses applications dans les industries de l'alimentation animale. INRA Prod. Anim. 2002, 15, 209-219.

37. Bertrand, D.; Dufour, E. La Spectroscopie Infrarouge et ses Applications Analytiques; Tec \& Doc Lavoisier: Paris, France, 2005; p. 692.

38. Geladi, P.; McDougel, D.; Martens, H. Linearization and scatter correction for near infrared reflectance spectra of meat. Appl. Spectrosc. 1985, 39, 491-500. [CrossRef]

39. Peiris, K.H.S.; Pumphrey, M.O.; Dowell, F.E. Nir absorbance characteristics of deoxynivalenol and of sound and fusarium-damaged wheat kernels. J. Near Infrared Spectrosc. 2009, 17, 213-221. [CrossRef]

40. Peiris, K.H.S.; Pumphrey, M.O.; Dong, Y.; Maghirang, E.B.; Berzonsky, W.; Dowell, F.E. Near-infrared spectroscopic method for identification of fusarium head blight damage and prediction of deoxynivalenol in single wheat kernels. Cereal Chem. 2010, 87, 511-517. [CrossRef]

41. Bezdekova, K.; Bradacova, M. A Verification of the Possibility of mycoToxin Determination in Barley Caryopses by Near-Infrared Spectroscopy; Škarpa, P., Ryant, P., Cerkal, R., Polak, O., Kovarnik, J., Eds.; Mendelova Univerzita v Brně: Brno, Czech Republic, 2013; pp. 634-638.

42. Stasiewicz, M.J.; Falade, T.D.O.; Mutuma, M.; Mutiga, S.K.; Harvey, J.J.W.; Fox, G.; Pearson, T.C.; Muthomi, J.W.; Nelson, R.J. Multi-spectral kernel sorting to reduce aflatoxins and fumonisins in kenyan maize. Food Control 2017, 78, 203-214. [CrossRef]

43. Dardenne, P.; Sinnaeve, G.; Baeten, V. Multivariate calibration and chemometrics for near infrared spectroscopy: Which method? J. Near Infrared Spectrosc. 2000, 8, 229-237. [CrossRef]

44. Tuffery, S. Data Mining and Statistics for Decision Making; John Wiley \& Sons, Inc.: Hoboken, NJ, USA, 2007; p. 533.

45. Tibola, C.S.; Fernandes, J.M.C.; Delanora, R. Predicting wheat mycotoxin content using near-infrared reflectance spectroscopy. In Proceedings of the 2010 National Fusarium Head Blight Forum, Milwaukee, WI, USA, 7-9 December 2010; Canty, S., Clark, A., Anderson-Scully, A., Ellis, E., Van Sanford, D., Eds.; University of Kentucky: Lexington, KY, USA; p. 121.

46. Dvoracek, V.; Prohaskova, A.; Chrpova, J.; Stockova, L. Near infrared spectroscopy for deoxynivalenol content estimation in intact wheat grain. Plant Soil Environ. 2012, 58, 196-203.

47. Gaspardo, B.; Del Zotto, S.; Torelli, E.; Cividino, S.R.; Firrao, G.; Della Riccia, G.; Stefanon, B. A rapid method for detection of fumonisins b-1 and b-2 in corn meal using fourier transform near infrared (ft-nir) spectroscopy implemented with integrating sphere. Food Chem. 2012, 135, 1608-1612. [CrossRef] [PubMed]

48. Della Riccia, G.; Del Zotto, S. A multivariate regression model for detection of fumonisins content in maize from near infrared spectra. Food Chem. 2013, 141, 4289-4294.

49. De Girolamo, A.; Cervellieri, S.; Visconti, A.; Pascale, M. Rapid analysis of deoxynivalenol in durum wheat by ft-nir spectroscopy. Toxins 2014, 6, 3129-3143. [CrossRef] [PubMed]

50. Levasseur-Garcia, C.; Kleiber, D. A method for the allotment of maize contaminated by toxins. J. Near Infrared Spectrosc. 2015, 23, 255-265. [CrossRef]

51. Wold, S.; Martens, H.; Wold, H. The multivariate calibration problem in chemistry solved by the pls method. In Lecture Notes in Mathematics; Ruhe, A., Kågström, B., Eds.; Springer Verlag: Heidelberg, Germany, 1982; pp. 286-293.

52. Borggard, C.; Thodberg, H.H. Optimal minimal neural interpretation of spectra. Anal. Chem. 1992, 64, 545-551. [CrossRef]

53. Williams, P.; Norris, K. Near-Infrared Technology in the Agricultural and Food Industries; American Association of Cereal Chemists Inc.: St. Paul, MN, USA, 1987; p. 330.

54. Naes, T.; Isaksson, T.; Fearn, T.; Davies, T. A User-Friendly Guide to Multivariate Calibration and Classification; NIR Publications: Chichester, UK, 2002. 
55. Givens, D.I.; De Boever, J.L.; Deaville, E.R. The principles, practices and some future applications of near infrared spectroscopy for predicting the nutritive value of foods for animals and humans. Nutr. Res. Rev. 1997, 10, 83-114. [CrossRef] [PubMed]

56. Miguel Gomez, M.A.; Bratos Perez, M.A.; Martin Gil, F.J; Duenas Diez, A.; Martin Rodriguez, J.F.; Gutierrez Rodriguez, P.; Orduna Domingo, A.; Rodriguez Torres, A. Identification of species of brucella using fourier transform infrared spectroscopy. J. Microbiol. Methods 2003, 55, 121-131. [CrossRef]

57. Fraenkel, H.; Gough, P.B.; Maughan, W.S. Method and Apparatus for Sorting Agricultural Products. U.S. Patent 4203522, 20 May 1980.

58. Davies, A.M.C.; Dennis, C.; Grant, A. Screening of tomato purée for excessive mould content by near-infrared spectroscopy : A preliminary evaluation. J. Sci. Food Agric. 1987, 39, 349-355. [CrossRef]

59. Draganova, T.; Daskalov, P.; Tsonev, R. An approach for identifying of fusarium infected maize grains by spectral analysis in the visible and near infrared region, simca models, parametric and neural classifiers. Int. J. Bioautom. 2010, 14, 119-128.

60. Tallada, J.G.; Wicklow, D.T.; Pearson, T.C.; Armstrong, P.R. Detection of fungus-infected corn kernels using near-infrared reflectance spectroscopy and color imaging. Trans. Asabe 2011, 54, 1151-1158. [CrossRef]

61. Peiris, K.H.S.; Bockus, W.W.; Dowell, F.E. Infrared spectral properties of germ, pericarp, and endosperm sections of sound wheat kernels and those damaged by fusarium graminearum. Appl. Spectrosc. 2012, 66, 1053-1060. [CrossRef]

62. Balut, A.L.; Clark, A.J.; Brown-Guedira, G.; Souza, E.; Van Sanford, D.A. Validation of fhb1 and qfhs.Nau-2dl in several soft red winter wheat populations. Crop Sci. 2013, 53, 934-945. [CrossRef]

63. Jin, F.; Bai, G.; Zhang, D.; Dong, Y.; Ma, L.; Bockus, W.; Dowell, F. Fusarium-damaged kernels and deoxynivalenol in fusarium-infected u.S. Winter wheat. Phytopathology 2014, 104, 472-478. [CrossRef] [PubMed]

64. Kautzman, M.E.; Wickstrom, M.L.; Scott, T.A. The use of near infrared transmittance kernel sorting technology to salvage high quality grain from grain downgraded due to fusarium damage. Anim. Nutr. 2015, 1, 41-46. [CrossRef]

65. Miedaner, T.; Han, S.; Kessel, B.; Ouzunova, M.; Schrag, T.; Utz, F.H.; Melchinger, A.E. Prediction of deoxynivalenol and zearalenone concentrations in fusarium graminearum inoculated backcross populations of maize by symptom rating and near-infrared spectroscopy. Plant Breed. 2015, 134, 529-534. [CrossRef]

66. Kos, G.; Sieger, M.; McMullin, D.; Zahradnik, C.; Sulyok, M.; Oner, T.; Mizaikoff, B.; Krska, R. A novel chemometric classification for ftir spectra of mycotoxin-contaminated maize and peanuts at regulatory limits. Food Addit. Contam. Part A 2016, 33, 1596-1607. [CrossRef] [PubMed]

67. Sieger, M.; Kos, G.; Sulyok, M.; Godejohann, M.; Krska, R.; Mizaikoff, B. Portable infrared laser spectroscopy for on-site mycotoxin analysis. Sci. Rep. 2017, 7, 44028. [CrossRef] [PubMed]

68. Alcalà, M.; Blanco, M.; Moyano, D.; Broad, N.W.; O’Brien, N.; Friedrich, D.; Pfeifer, F.; Siesler, H.W. Qualitative and quantitative pharmaceutical analysis with a novel hand-held miniature near infrared spectrometer. J. Near Infrared Spectrosc. 2013, 21, 445-457. [CrossRef]

69. Williams, P.C. Implementation of near-infrared technology. In Near Infrared Technology in the Agricultural and Food Industries, 2nd ed.; Williams, P., Norris, K., Eds.; American Association of Cereal Chemists: St. Paul, MN, USA, 2001.

70. Hirano, S.; Okawara, N.; Narazaki, S. Near infrared detection of internally moldy nuts. Biosci. Biotechnol. Biochem. 1998, 62, 102-107. [CrossRef] [PubMed]

71. De Girolamo, A.; Lippolis, V.; Nordkvist, E.; Visconti, A. Rapid and non-invasive analysis of deoxynivalenol in durum and common wheat by fourier-transform near infrared (ft-nir) spectroscopy. Food Addit. Contam. Part A 2009, 26, 907-917. [CrossRef] [PubMed]

72. Krska, R.; Schubert-Ullrich, P.; Molinelli, A.; Sulyok, M.; Macdonald, S.; Crews, C. Mycotoxin analysis: An update. Food Addit. Contam. 2008, 25, 152-163. [CrossRef] [PubMed]

73. Shepherd, K.D.; Walsh, M.G. Infrared spectroscopy-Enabling an evidence-based diagnostic surveillance approach to agricultural and environmental management in developing countries. J. Near Infrared Spectrosc. 2007, 15, 1-19. [CrossRef]

74. Norris, K. Hazards with near infrared spectroscopy in detecting contamination. J. Near Infrared Spectrosc. 2009, 17, 165-166. [CrossRef] 
75. Levasseur-Garcia, C.; Bailly, S.; Kleiber, D.; Bailly, J.-D. Assessing risk of fumonisin contamination in maize using near-infrared spectroscopy. J. Chem. 2015, 2015, 10. [CrossRef]

76. Copetti, M.V.; Iamanaka, B.T.; Pereira, J.L.; Lemes, D.P.; Nakano, F.; Taniwaki, M.H. Co-occurrence of ochratoxin a and aflatoxins in chocolate marketed in brazil. Food Control 2012, 26, 36-41. [CrossRef]

77. Pei-Shih, L. Infrared spectroscopy detection of fungal infections and mycotoxins for food safety concerns. J. Infect. Dis. Ther. 2015, 3, 241.

78. Lattanzio, V.M.T.; Pascale, M.; Visconti, A. Current analytical methods for trichothecene mycotoxins in cereals. TrAC Trends Anal. Chem. 2009, 28, 758-768. [CrossRef]

79. Dall'Asta, C.; Battilani, P. Fumonisins and their modified forms, a matter of concern in future scenario? World Mycotoxin J. 2016, 9, 727-739. [CrossRef]

80. Mignani, A.G.; Ciaccheri, L.; Mencaglia, A.A.; De Girolamo, A.; Lippolis, V.; Pascale, M. In Rapid screening of wheat bran contaminated by deoxynivalenol mycotoxin using raman spectroscopy: A preliminary experiment. In Proceedings of the Sixth European Workshop on Optical Fibre Sensors (EWOFS'2016), Limerick, Ireland, 31 May-3 June 2016; p. 99160W.

81. Gowen, A.A.; O’Donnell, C.P.; Cullen, P.J.; Downey, G.; Frias, J.M. Hyperspectral imaging-An emerging process analytical tool for food quality and safety control. Trends Food Sci. Technol. 2007, 18, 590-598. [CrossRef]

82. Arnal Barbedo, J.G.; Tibola, C.S.; Pontes Lima, M.I. Deoxynivalenol screening in wheat kernels using hyperspectral imaging. Biosyst. Eng. 2017, 155, 24-32. [CrossRef]

83. Dale, L.M.; Thewis, A.; Boudry, C.; Rotar, I.; Dardenne, P.; Baeten, V.; Pierna, J.A.F. Hyperspectral imaging applications in agriculture and agro-food product quality and safety control: A review. Appl. Spectrosc. Rev. 2013, 48, 142-159. [CrossRef]

84. Del Fiore, A.; Reverberi, M.; Ricelli, A.; Pinzari, F.; Serranti, S.; Fabbri, A.A.; Bonifazi, G.; Fanelli, C. Early detection of toxigenic fungi on maize by hyperspectral imaging analysis. Int. J. Food Microbiol. 2010, 144, 64-71. [CrossRef] [PubMed] 